\title{
EFEKTIVITAS PENERAPAN MODEL PEMECAHAN MASALAH DDFK (DEFINISI, DESAIN, FORMULASI, DAN KOMUNIKASI) DALAM MENINGKATKAN KEMAMPUAN PEMAHAMAN KONSEP MATEMATIKA SISWA
}

\author{
Hafsyah, Hafsyah \\ Program Studi Pendidikan Matematika, STKIP Muhammadiyah Enrekang, Indonesia \\ E-mail: a.hafsyah@yahoo,com.
}

\begin{abstract}
ABSTRAK
Penelitian ini bertujuan untuk (1) Mengetahui kemampuan pemahaman konsep matematika sebelum penerapan Model Pemecahan Masalah DDFK. (2) Mengetahui kemampuan pemahaman konsep matematika sesudah penerapan Model Pemecahan Masalah DDFK. (3) Mengetahui Efektivitas Penerapan Model Pemecahan Masalah DDFK terhadap peningkatan kemampuan pemahaman konsep matematika. Jenis penelitian ini merupakan penelitian preeksperimental design dengan One-Group Pretest-Posttes Design. Sampel dalam penelitian ini adalah seluruh siswa kelas $\mathrm{X}_{4}$ SMA Negeri 11 Makassar yang berjumlah 40 siswa terdiri dari 1 kelas. Sampel diambil secara random atau acak karena terdiri dari 9 kelas. Instrumen yang digunakan penulis dalam penelitian ini adalah tes kemampuan pemahaman konsep matematika siswa yang terkait dengan materi Trigonometri, dan lembar observasi. Pengolahan data yang dilakukan penulis dalam hal ini adalah dengan menggunakan analisis statistik.

Berdasarkan hasil analisis data deskriptif menunjukkan bahwa rata-rata kemampuan pemahaman konsep matematika sebelum penerapan Model Pemecahan Masalah DDFK adalah 50,88 sedangkan rata-rata kemampuan pemahaman konsep matematika setelah penerapan Model Pemecahan Masalah DDFK adalah 78,50. Adapun analisis statistik inferensial untuk instrumen dalam bentuk tes menunjukkan nilai $s_{1}^{2}=135,60$ dan nilai $s_{2}^{2}=68,36$ sehingga nilai $\mathrm{F}$ yang dicari $=1,98$. Dengan demikian $\mathrm{s}_{1}^{2}>\mathrm{s}_{2}^{2}$ atau $\mathrm{F}>0$, berarti model pemecahan masalah DDFK efektif dalam meningkatkan kemampuan pemahaman konsep matematika siswa kelas $\mathrm{X}_{4} \mathrm{SMA}$ Negeri 11 Makassar.
\end{abstract}

Kunci: Model Pemecahan Masalah DDFK, Pemahaman Konsep Matematika

Hafsyah, H. (2018). Efektivitas Penerapan Model Pemecahan Masalah DDFK (Definisi, Desain, Formulasi, dan Komunikasi) dalam Meningkatkan Kemampuan Pemahaman Konsep Matematika Siswa. Edumaspul - Jurnal Pendidikan, 2(1), 24-39. 


\section{PENDAHULUAN}

Erman Suherman (2003:25) Matematika disebut sebagai ratunya ilmu atau ibunya ilmu. Maksudnya matematika merupakan kunci utama dari ilmu-ilmu pengetahuan lain. Matematika juga merupakan ilmu dasar yang memegang peranan penting dalam perkembangan ilmu pengetahuan dan teknologi. Oleh karena itu, untuk menguasai dan menciptakan teknologi di masa depan diperlukan penguasaan matematika yang kuat sejak dini.

Matematika merupakan salah satu bidang studi yang harus diberikan kepada peserta didik pada setiap jenjang pendidikan, mulai dari sekolah dasar untuk membekali peserta didik dengan kemampuan berpikir logis, analitis, sistematis, kritis, dan kreatif, serta kemampuan bekerjasama.

Erman Suherman (2003:25) Fungsi mata pelajaran matematika adalah sebagai alat, pola pikir, dan ilmu atau pengetahuan. Matematika dipelajari melalui pendidikan formal mempunyai peranan penting bagi siswa sebagai bekal pengetahuan untuk membentuk sikap serta pola pikirnya. Lebih rinci lagi dikemukakan oleh Ruseffendi (2005:208) bahwa dengan belajar matematika:

1. Kita mampu berhitung dan mampu melakukan perhitungan-perhitungan lainnya,

2. Kita memiliki persyaratan untuk belajar bidang studi lain,

3. Perhitungan menjadi lebih sederhana dan praktis, dan

4. Kita diharapkan menjadi manusia yang tekun, kritis, logis, bertanggung jawab, dan mampu menyelesaikan permasalahan.

Hal tersebut menunjukkan betapa pentingnya matematika dalam kehidupan.
Namun, pada kenyataannya di kalangan para siswa masih muncul anggapan bahwa pelajaran matematika itu sukar dan kurang disenangi. Kebanyakan dari mereka tidak senang dengan matematika karena rumus atau definisi dalam matematika terlalu banyak dan sukar dipahami. Sehingga tidak sedikit siswa yang tidak mempersiapkan materi yang akan dipelajari terlebih dahulu dan siswa hanya datang tanpa bekal pengetahuan.

Yusefendi (2010) Ada beberapa faktor yang dianggap mengapa matematika itu sulit untuk dipahami oleh siswa antara lain:

1. Rendahnya tingkat pemahaman konsep siswa terhadap matematika.

2. Rendahnya daya nalar siswa untuk mengaitkan antara satu masalah dengan masalah yang lain secara matematis.

3. Model pembelajaran yang kurang memberikan kesempatan kepada siswa untuk mengembangkan potensi yang ada pada diri siswa.

4. Siswa beranggapan bahwa matematika sebagai beban yang memberatkan.

Hamzah B, Uno (2007: 126) Sementara itu, salah satu kemampuan dasar yang harus dicapai dalam bidang matematika adalah kemampuan pemahaman konsep, yang juga merupakan salah satu tujuan pembelajaran matematika di sekolah yang terdapat dalam panduan KTSP, yaitu siswa mampu memahami konsep matematika, menjelaskan keterkaitan antar konsep dan mengaplikasikan konsep atau algoritma secara luwes, akurat, efisien, dan tepat dalam pemecahan masalah.

Hal ini disebabkan siswa hanya mempelajari matematika cenderung pada konsep berhitung dan beralgoritma tanpa menekankan pada pemahaman konsep, yang akibatnya siswa hanya mampu menyelesaikan soal-soal yang bersifat rutin. 
Padahal apabila siswa benar-benar memahami konsep, bagaimanapun bentuk soalnya siswa akan mampu menyelesaikannya.

Salah satu usaha yang dapat dilakukan untuk mengatasi persoalan tersebut bagi seorang guru adalah dengan memilih strategi pembelajaran, baik berupa pendekatan, model, ataupun metode pembelajaran yang efektif dalam mengajarkan matematika sehingga diharapkan konsep-konsep matematika yang disampaikan dapat dipahami oleh siswa dengan lebih baik karena salah satu kunci keberhasilan pembelajaran matematika di sekolah adalah kreativitas dan inovasi guru dalam mengajar.

Untuk meningkatkan kemampuan pemahaman konsep matematika siswa, diperlukan suatu pembelajaran yang mengeksplorasi suatu masalah agar dapat menunjukkan pemahamannya yang diperoleh dari masalah tersebut sehingga siswa dapat menjelaskan keterkaitan antar konsep dan mengaplikasikan konsep atau algoritma secara luwes, akurat, efisien, dan tepat.

Kusmawan (1998:1) Salah satu model pembelajaran yang dapat digunakan untuk meningkatkan kemampuan pemahaman konsep matematika siswa adalah model pemecahan masalah "DDFK". Istilah "DDFK" dalam model ini merupakan kependekan dari keempat istilah, yaitu Definisi, Desain, Formulasi, dan Komunikasi. Maksudnya adalah dalam menyelesaikan suatu masalah dilakukan beberapa tahapan pemecahan masalah, yaitu mendefinisikan masalah, mendesain solusi, memformulasikan hasil, dan mengomunikasikan hasil. Secara teoritis, pembelajaran ini didasarkan atas prinsip prinsip problem solving yaitu, memahami masalah, merencanakan penyelesaian, menyelesaikan masalah sesuai rencana, dan melakukan pengecekan kembali terhadap semua langkah yang telah dikerjakan.

Melalui proses pemecahan masalah ini, menurut Pizzini (dalam Kusmawan, 1989:1) para siswa akan mampu menjadi pemikir yang handal dan mandiri. Mereka dirangsang untuk mampu menjadi seorang eksplorer (mencari penemuan terbaru), inventor (mengembangkan ide/gagasan dan pengujian baru yang inovatif), desainer (mengkreasi rencana dan model terbaru), mengambil keputusan (berlatih bagaimana menetapkan pilihan yang bijaksana), dan sebagai komunikator (mengembangkan metode dan teknik untuk bertukar pendapat dan berinteraksi).

Abidah (2008:15) Adapun langkahlangkah model pemecahan masalah DDFK terlihat pada tabel berikut:

Tabel: 1

\section{Langkah-langkah Model Pemecahan} Masalah DDFK

\begin{tabular}{|l|l|l|}
\hline Fase-1 & $\begin{array}{l}\text { Tingkah Laku } \\
\text { Guru }\end{array}$ & $\begin{array}{l}\text { Tingkah Laku } \\
\text { Siswa }\end{array}$ \\
\hline $\begin{array}{l}\text { Menyampaik } \\
\text { an tujuan } \\
\text { pembelajaran } \\
\text { dan } \\
\text { memotivasi } \\
\text { siswa. }\end{array}$ & $\begin{array}{l}\text { Guru } \\
\text { menyampaikan } \\
\text { tujuan } \\
\text { pembelajaran } \\
\text { yang ingin dan } \\
\text { dicapai } \\
\text { memotivasi siswa } \\
\text { belajar. }\end{array}$ & $\begin{array}{l}\text { Siswa } \\
\text { menyimak } \\
\text { dengan baik } \\
\text { penjelesan dari } \\
\text { guru. }\end{array}$ \\
\hline $\begin{array}{l}\text { Fase-2 } \\
\text { Menyajikan } \\
\text { informasi }\end{array}$ & $\begin{array}{l}\text { Tingkah Laku } \\
\text { Guru menyajikan } \\
\text { informasi kepada } \\
\text { siswa melalui } \\
\text { bahan ajar (LKS) } \\
\text { secara individual } \\
\text { maupun } \\
\text { kelompok. }\end{array}$ & $\begin{array}{l}\text { Siswa } \\
\text { memperhatikan } \\
\text { dengan } \\
\text { penjelasan dari } \\
\text { guru. }\end{array}$ \\
\hline
\end{tabular}




\begin{tabular}{|c|c|c|}
\hline Fase-3 & $\begin{array}{l}\text { Tingkah Laku } \\
\text { Guru }\end{array}$ & $\begin{array}{c}\text { Tingkah Laku } \\
\text { Siswa }\end{array}$ \\
\hline $\begin{array}{l}\text { Pembelajaran } \\
\text { individual } \\
\text { atau } \\
\text { berkelompok }\end{array}$ & $\begin{array}{l}\text { Guru menentukan } \\
\text { apakah siswa } \\
\text { dalam } \\
\text { menyelesaikan } \\
\text { bahan ajar secara } \\
\text { individual atau } \\
\text { berkelompok }\end{array}$ & $\begin{array}{l}\text { Siswa } \\
\text { menyelesaikan } \\
\text { bahan ajar } \\
\text { sesuai dengan } \\
\text { petunjuk guru }\end{array}$ \\
\hline Fase-4 & $\begin{array}{ll}\text { Tingkah Laku } \\
\text { Guru }\end{array}$ & $\begin{array}{c}\text { Tingkah Laku } \\
\text { Siswa }\end{array}$ \\
\hline $\begin{array}{l}\text { Pemecahan } \\
\text { masalah }\end{array}$ & $\begin{array}{l}\text { Guru } \\
\text { memberikan } \\
\text { LKS/ suatu } \\
\text { masalah untuk } \\
\text { diselesaikan oleh } \\
\text { siswa. } \\
\text { Selanjutnya guru } \\
\text { membimbing saat } \\
\text { mengerjakan } \\
\text { LKS. }\end{array}$ & $\begin{array}{l}\text { Siswa } \\
\text { mengerjakan } \\
\text { tugas yang } \\
\text { diberikan guru } \\
\text { dan bertanya } \\
\text { apabila } \\
\text { mengalami } \\
\text { kesulitan dalam } \\
\text { mengerjakan } \\
\text { tugas tersebut. }\end{array}$ \\
\hline Fase-5 & $\begin{array}{l}\text { Tingkah Laku } \\
\text { Guru }\end{array}$ & $\begin{array}{c}\text { Tingkah Laku } \\
\text { Siswa }\end{array}$ \\
\hline Evaluasi & $\begin{array}{l}\text { Guru membrikan } \\
\text { kesmpatan } \\
\text { kepada siswa } \\
\text { mempersentaseka } \\
\mathrm{n} \text { hasil belajar di } \\
\text { depan kelas. }\end{array}$ & $\begin{array}{l}\text { Siswa } \\
\text { mempersentase } \\
\text { kan hasil } \\
\text { belajar di } \\
\text { depan kelas. }\end{array}$ \\
\hline Fase-6 & $\begin{array}{l}\text { Tingkah Laku } \\
\text { Guru }\end{array}$ & $\begin{array}{c}\text { Tingkah Laku } \\
\text { Siswa }\end{array}$ \\
\hline $\begin{array}{l}\text { Memberi } \\
\text { penghargaan }\end{array}$ & $\begin{array}{lr}\text { Guru mencari } \\
\text { cara } \\
\text { menghargai baik } \\
\text { upaya maupun } \\
\text { hasil belajar } \\
\text { individu dan } \\
\text { kelompok dalam } \\
\text { pemecahan } \\
\text { masalah. }\end{array}$ & $\begin{array}{l}\text { Siswa } \\
\text { mengumpulkan } \\
\text { hasil } \\
\text { pekerjaannya } \\
\text { untuk } \\
\text { mendapatkan } \\
\text { penghargaan } \\
\text { dari guru. }\end{array}$ \\
\hline
\end{tabular}

Penelitian ini telah dilakukan sebelumnya oleh Vera Khairunnisa (2010:46) dengan judul Perbandingan Peningkatan Kemampuan Pemahaman Konsep Matematis Antara Siswa yang Memperoleh Pembelajaran Melalui Model Pemecahan Masalah "DDFK” dengan yang
Memperoleh Pembelajaran Konvensional. Subyek penelitian ini adalah siswa kelas IX SMP Pasundan 3 Bandung pada tahun ajaran 2010/2011 dengan sampel siswa kelas IX A sebagai kelompok eksperimen yaitu kelas yang memperoleh pembelajaran matematika model pemecahan masalah "DDFK" dan siswa kelas IX D sebagai kelompok kontrol yaitu kelas yang memperoleh pembelajaran konvensional. Instrumen penelitian yang digunakan berupa tes kemampuan pemahaman konsep matematis (pretes dan postes) serta lembar observasi.

Hasil yang diperoleh dari penelitian tersebut adalah skor rata-rata untuk kelas eksperimen $51 \%$ dan kelas kontrol $37 \%$. Sehingga berdasarkan penelitian tersebut dapat disimpulkan bahwa kemampuan pemahaman konsep matematis siswa yang memperoleh pembelajaran matematika melalui model pemecahan masalah "DDFK" lebih baik daripada siswa yang memperoleh pembelajaran konvensional.

Berdasarkan latar belakang di atas, maka rumusan masalah dalam penelitian ini adalah: (1) Bagaimana kemampuan pemahaman konsep matematika sebelum diterapkan Model Pemecahan Masalah DDFK pada siswa kelas X SMA Negeri 11 Makassar, (2) Bagaimana kemampuan pemahaman konsep matematika setelah diterapkan Model Pemecahan Masalah DDFK pada siswa kelas X SMA Negeri 11 Makassar, (3) Apakah penerapan model pemecahan masalah DDFK efektif dalam meningkatkan kemampuan pemahaman konsep matematika pada siswa kelas X SMA Negeri 11 Makassar.

Adapun tujuan yang ingin dicapai dalam penelitian ini adalah untuk mengetahui (1) Kemampuan pemahaman konsep matematika sebelum penerapan Model Pemecahan Masalah DDFK pada 
siswa kelas X SMA Negeri 11 Makassar. (2) Kemampuan pemahaman konsep matematika sesudah penerapan Model Pemecahan Masalah DDFK pada siswa kelas X SMA Negeri 11 Makassar. (3) Efektivitas penerapan Model Pemecahan Masalah DDFK terhadap peningkatan kemampuan pemahaman konsep matematika pada siswa kelas $X$ SMA Negeri 11 Makassar.

Manfaat hasil penelitian ini diharapkan dapat bermanfaat dan memberikan informasi kepada berbagai pihak yang terlibat dalam dunia pedididkan khususnya pada pembelajaran matematika. Manfaat yang diharapkan antara lain sebagai berikut: (1) Bagi Siswa: dapat memahami dengan mudah konsep matematika dengan menggunakan Model Pemecahan Masalah DDFK. (2) Bagi Guru: sebagai masukan dalam menentukan berbagai langkah penanganan terhadap siswa yang mengalami masalah dengan peningkatan hasil belajar matematika baik di sekolah maupun di luar sekolah serta sebagai masukan dalam memilih model pembelajaran yang sesuai dan efesien untuk mencapai tujuan pembelajaran. (3) Bagi Peneliti: sebagai acuan dan masukan dalam mengembangkan penelitian di masa mendatang serta menjadi referensi sebagai calon pendidik.(4) Bagi Sekolah: penelitian ini sebagai bahan masukan dalam rangka perbaikan pembelajaran sehingga dapat menunjang tercapainya hasil belajar mengajar sesuai dengan harapan

\section{KAJIAN PUSTAKA}

\section{PEMAHAMAN KONSEP MATEMATIKA}

Erman Suherman (2003: 33)

Pemahaman konsep terdiri atas dua kata, yaitu pemahaman dan konsep. Menurut Gagne konsep adalah "ide abstrak yang memunginkan kita dapat mengelompokkan objek ke dalam contoh dan non contoh".

Ratna Wilis (2006:61) Meskipun banyak definisi tentang konsep yang diungkapkan para ahli, namun beberapa ciri umum konsep yaitu:

a. Konsep merupakan buah pikiran yang dimiliki seseorang ataupun sekelompok orang.

b. Konsep timbul sebagai hasil dari pengalaman, lebih dari sekedar satu benda, peristiwa atau fakta. Konsep itu adalah suatu generalisasi.

c. Konsep adalah hasil berpikir abstrak manusia yang merangkum banyak pengalaman.

d. Konsep merupakan kaitan fakta-fakta atau pemberian pola pada fakta-fakta.

e. Suatu konsep dianggap bersangkutan harus mengalami perubahan.

Pemahaman berasal dari kata dasar paham, yang berarti mengerti benar. Seseorang dapat dikatakan paham terhadap suatu hal, apabila orang tersebut mengerti benar dan mampu menjelaskan suatu hal yang dipahaminya. Sehingga pemahaman konsep matematika adalah mengerti benar tentang konsep matematika. Istilah pemahaman yang digunakan dalam penelitian ini, adalah kata understanding.

Selanjutnya Kilpatrick dan Findell (dalam Dasari (2002:71) mengemukakan indikator pemahaman konsep, yaitu:

a. Kemampuan menyatakan ulang konsep yang telah dipelajari.

b. Kemampuan mengklasifikasikan objekobjek berdasarkan dipenuhi atau tidaknya persyaratan yang membentuk konsep tersebut.

c. Kemampuan menerapkan konsep secara algoritma. 
d. Kemampuan memberikan contoh dan counter example dari konsep yang telah dipelajari.

e. Kemampuan menyajikan konsep dalam berbagai macam bentuk representasi matematika.

f. Kemampuan mengaitkan berbagai konsep (internal dan eksternal matematika).

g. Kemampuan mengembangkan syarat perlu dan syarat cukup suatu konsep.

Sedangkan pemahaman konsep menurut Skemp (dalam Fadjar Shadiq (2008:10)) terbagi atas dua bagian pemahaman, yaitu pemahaman instrumental dan pemahaman relasional. Pemahaman instrumental diartikan sebagai pemahaman atas konsep yang saling terpisah dan hanya hafal rumus dalam perhitungan sederhana. Dalam hal ini siswa hanya memahami urutan pengajaran atau algoritma. Sedangkan pada pemahaman relasional termuat skema atau struktur yang dapat digunakan pada penyelesaian masalah yang lebih luas dan sifat pemakaiannya lebih bermakna. Siswa yang telah memiliki pemahaman relasional dapat mengaitkan suatu konsep lainnya secara benar dan menyadari proses yang dilakukan.

Proses pembelajaran yang bertujuan agar siswa memiliki pemahaman instrumental, yaitu siswa sering mempelajari bagian demi bagian suatu algoritma, siswa cenderung bergantung pada petunjuk untuk menyelesaikan tugas yang baru. Sedangkan proses pembelajaran yang bertujuan agar siswa memiliki pemahaman relasional yaitu, siswa harus membangun struktur konseptual sehingga mereka dapat menghasilkan banyak skema rencana penyelesaian.

Berdasarkan uraian di atas dapat dikemukakan bahwa pemahaman konsep matematika adalah kemampuan siswa dalam menerjemahkan, menafsirkan, dan menyimpulkan suatu konsep matematika berdasarkan pembentukan pengetahuannya sendiri, bukan sekedar menghapal. Selain itu, siswa dapat menemukan dan menjelaskan kaitan suatu konsep dengan konsep lainnya. Pemahaman konsep dapat membantu siswa untuk mengingat. Hal tersebut dikarenakan ide-ide matematika yang siswa peroleh dengan memahami saling berkaitan, sehingga siswa lebih mudah untuk mengingat dan menggunakan, serta menyusunnya kembali saat lupa. Siswa mengingat kembali apa yang mereka ingat dan mencoba menggambarkan dengan menggunakan pemikiran sendiri.

Pemahaman merupakan aspek yang sangat penting dalam pembelajaran matematika, karena dengan memahami konsep, siswa dapat mengembangkan kemampuannya dalam pembelajaran matematika, siswa dapat menerapkan konsep yang telah dipelajarinya untuk menyelesaikan permasalahan sederhana sampai dengan yang kompleks.

\section{PEMECAHAN MASALAH}

Afni (2007:12) Pemecahan masalah adalah proses yakni pemecahan masalah muncul sebagai suatu kegiatan yang dinamis yang memerlukan metode, strategi, dan prosedur yang digunakan siswa dalam menyelesaikan masalah hingga menemukan jawaban. Dalam pemecahan masalah siswa didorong dan diberi kesenpatan seluasluasnya untuk berinisiatif dan berpikir sistematis dalam menghadapi suatu masalah dengan menerapkan pengetahuan yang didapat sebelumnya.

Berhadapan dengan sesuatu yang tidak rutin dan kemudian mencoba menyelesaikannya merupan ciri khas makhluk hidup yang berakal. Pemecahan masalah (problem solving) merupakan 
latihan bagi siswa untuk berhadapan dengan sesuatu yang tidak rutin dan kemudian mencoba menyelesaikannya. Ini adalah salah satu kompetensi yang harus ditumbuhkan pada diri siswa. Kompetensi seperti ini ditumbuhkan melalui bentuk pemecahan masalah.

Erman Suherman (2003:92) Suatu masalah biasanya memuat situasi yang mendorong seseorang untuk menyelesaikannya, akan tetapi tidak tahu secara langsung apa yang harus dikerjakan untuk menyelesaikannya. Jika suatu masalah diberikan kepada seorang anak dan anak tersebut langsung mengetahui cara menyelesaikannya dengan benar, maka soal tersebut tidak dapat dikatakan sebagai masalah.

Berbicara tentang pemecahan masalah tidak bisa dilepaskan dari tokoh utamanya yaitu George Poyla. Menurut Polya (dalam Erman Suherman (2003:99)), dalam pemecahan suatu masalah terdapat empat langkah yang harus dilakukan yaitu:

1. Memahami masalah

2. Merencanakan pemecahannya

3. Menyelesaikan masalah sesuai rencana langkah kedua

4. Memeriksa kembali hasil yang diperoleh

Oleh karena itu pemecahan masalah merupakan proses menerapkan pengetahuan siswa yang telah diperoleh sebelumnya ke dalam situasi baru yang belum dikenal.

\section{MODEL PEMECAHAN MASALAH DDFK}

Menurut Kusmawan (1998:1) istilah DDFK dalam model ini merupakan kependekan dari dari empat istilah, yaitu definisi, desain, formulasi, dan komunikasi. Maksudnya dalam menyelesaikan suatu masalah dilakukan beberapa tahapan pemecahan masalah, yaitu mendefinisikan masalah, mendesain solusi, memformulasikan hasil, dan mengomunikasikan hasil.

Dalam model pemecahan masalah DDFK ini, proses yang diharapkan oleh model pembelajaran ini tidak boleh kaku, melainkan fleksibel terhadap kemungkinan kemunculan variasi permasalahan yang ada, karena hal tersebut tidak menguntungkan untuk suatu penyelesaian yang relatif baru. Dengan pendekatan model seperti ini, para siswa dibimbing untuk mengidentifikasi pengetahuan apa yang telah diketahuinya, dan mengembangkan pemahamannya atas pengetahuan tersebut melalui kegiatan pemecahan masalah.

Kusmawan (1998:6) mengungkapkan bahwa model pemecahan masalah DDFK memfasilitasi para siswa untuk memperoleh kesempatan dalam berbagai situasi, diantaranya adalah sebagai berikut:

a. Mempelajari dan memperdalam konsepkonsep dasar dengan bermakna.

b. Memanipulasi informasi yang diperoleh.

c. Mengembangkan keterampilan berpikir tingkat tinggi.

d. Menumbuhkan minat dan kepercayaan diri melalui pemecahan masalah.

e. Bertanggung jawab atas kritikan evaluatif yang kemungkinan disampaikan oleh siswa lain.

f. Mengintegrasikan konsep-knsep matematika ke dalam kurikulum.

g. Mengepresikan pengalamannya baik secara lisan maupun tulisan.

Kusmawan (1998:7) Sejalan dengan istilah DDFK (Definisi, Desain, Formulasi, Kominikasi), maka dalam penelitian ini kerangka kerja guru selama pembelajaran 
melelui model pemecahan masalah DDFK secara rinci dijelaskan sebagai berikut:

a. Mendefinisikan masalah meliputi: identiifikasi masalah, definisikan masalah, eksplorasi pengetahuan, dan formulasi pertanyaan. Sehingga kerangka kerja guru dalam fase mendefinisikan masalah, yaitu:

1) Menciptakan situasi dan kondisi yang kondusif.

2) Menciptakan situasi yang memudahkan munculnya pertanyaan.

3) Membantu menjelaskan permasalahan yang muncul.

b. Mendesain solusi meliputi: perencanaan solusi, penetapan prosedur penyelesaian, dan seleksi alat pengumpulan data.

1) Memberikan petunjuk tentang konsep matematika yang dapat digunakan untuk memecahkan permasalahan yang muncul.

2) Mengarahkan siswa dengan mengajukan pertanyaan-pertanyaan untuk membantu memperjelas arah dan logika berpikir siswa.

3) Menciptakan situasi yang menantang bagi siswa untuk berpikir.

c. Memformulasikan hasil meliputi: menggunakan dan memodifikasi data serta fakta.

1) Mengarahkan siswa agar lebih teliti dalam memformulasikan proses pemecahan masalah.

2) Memonitoring siswa untuk mengetahui pemahaman siswa mengenai penerapan desain yang telah dibuat.

d. Mengomunikasikan hasil.

Menciptakan situasi yang mendukung siswa untuk mengomunikasikan hasil pekerjaannya.
Melalui pendekatan model pemecahan masalah DDFK ini, para siswa dibimbing untuk mengidentifikasi pengetahuan apa yang telah diketahuinya, dan mengembangkan pemahamannya atas pengetahuan tersebut melalui kegiatan pemecahan masalah.

\section{METODE PENELITIAN}

Jenis Penelitian ini merupakan jenis penelitian pre-eksperimental design, dikatakan pre-eksperimental design karena penelitian ini belum merupakan eksperimen sungguh-sungguh. Desain penelitian yang digunakan yaitu One-Group Pretest-Posttest Design yaitu eksperimen yang dilaksanakan pada satu kelompok saja tanpa kelompok pembanding. Pada desain ini menggunakan pretest sebelum diberi perlakuan. Dengan demikian hasil perlakuan dapat diketahui lebih akurat, karena dapat membandingkan keadaan sebelum perlakuan. Secara umum desain penelitian ini digambarkan sebagai berikut:

\begin{tabular}{|ccc|}
\hline Pretest & Perlakuan & Posttest \\
$\mathrm{O}_{1}$ & $\mathrm{X}$ & $\mathrm{O}_{2}$ \\
\hline
\end{tabular}

Keterangan:

$\mathrm{O}_{1}=$ Kemampuan pemahaman konsep sebelum diterapkan Model pemecahan masalah DDFK

$\mathrm{X}=$ Perlakuan

$\mathrm{O}_{2}=$ Kemampuan pemahaman konsep setelah diterapkan Model pemecahan masalah DDFK

Tingkat efektivitas belajar $=\mathrm{O}_{2}-\mathrm{O}_{1}$

Populasi dalam penelitian ini adalah siswa Kelas X SMA Negeri 11 Makassar yang terdiri atas 9 kelas dengan jumlah siswa perkelas sebanyak 40 orang. Sehingga banyaknya populasi berjumlah 360 orang. 
Mengingat besarnya populasi yang ada maka perlu diambil sampel. Dalam penelitian ini sampel diambil dengan teknik random atau acak sehingga semua subjek-subjek dianggap sama karena sistem pembagian kelas pada SMA Negeri 11 Makassar ini menggunakan sistem pemerataan. Dengan demikian peneliti memberi hak yang sama kepada setiap subjek untuk memperoleh kesempatan dipilih menjadi sampel. Dalam penelitian ini sampel yang terpilih adalah kelas $\mathrm{X}_{4}$ dengan jumlah siswa 40 orang, $11 \%$ dari populasi.

Dalam penelitian ini menggunakan tiga jenis instrumen yaitu (1) berupa tes kemampuan pemahaman konsep, dan (2) pedoman observasi yang terdiri dari pedoman observasi guru dan siswa. Tes kemampuan pemahaman konsep yang akan digunakan adalah tes kemampuan pemahaman bentuk essay. Sedangkan pedoman observasi digunakan untuk memperoleh data tentang kinerja dan aktivitas siswa dalam mengikuti pembelajaran dengan menggunakan model pemecahan masalah DDFK.

\section{HASIL PENELITIAN DAN}

\section{PEMBAHASAN}

\section{Analisis Deskriptif}

\section{A. Analisis deskriptif Kemampuan Pemahaman Konsep Matematika Sebelum Penerapan Model Pemecahan Masalah DDFK di Kelas $\mathrm{X}_{4}$ SMA Negeri 11 Makassar.}

Hasil belajar siswa dideskripsikan berdasarkan analisis data tes awal (pre-test) dan data akhir (post-test). Data kemampuan pemahaman konsep matematika siswa kelas $\mathrm{X}_{4}$ SMA Negeri 11 Makassar sebelum penerapan model pemecahan masalah
$D D F K$ sebagai berikut mempunyai rata-rata (mean)

$$
\begin{aligned}
\bar{x} & =\frac{\sum_{i=1}^{k} x_{i}}{n} \\
& =\frac{2035}{40} \\
& =50,88
\end{aligned}
$$

Dari hasil perhitungan di atas diperoleh rata-rata nilai kemampuan pemahaman konsep matematika siswa kelas $\mathrm{X}_{4}$ SMA Negeri 11 Makassar sebelum penerapan model pemecahan masalah $D D F K$ yaitu 50,88 dari ideal 100 .

Tabel 2

Tingkat Penguasaan Materi (Pretest) Siswa Kelas IX $C_{2}$ SMP Negeri 5

\section{Makassar}

\begin{tabular}{|c|c|c|c|c|}
\hline $\begin{array}{c}\mathrm{N} \\
\mathrm{o}\end{array}$ & Interval & Frekuensi & $\begin{array}{c}\text { Perse } \\
\text { ntase }\end{array}$ & $\begin{array}{c}\text { Kategori Hasil } \\
\text { Belajar }\end{array}$ \\
\hline 1 & $0-34$ & 3 & 7,5 & Sangat Rendah \\
2 & $35-54$ & 20 & 50 & Rendah \\
3 & $55-64$ & 10 & 25 & Sedang \\
4 & $65-84$ & 7 & 17,5 & Tinggi \\
5 & $85-100$ & 0 & 0 & Sangat tinggi \\
\hline \multicolumn{2}{|c|}{ Jumlah } & 40 & 100 & \\
\hline
\end{tabular}

a. $\mathrm{P}=\frac{F}{N} \times 100 \%$

$$
=\frac{3}{40} \times 100 \%
$$$$
=7,5 \%
$$

b. $\mathrm{P}=\frac{F}{N} \times 100 \%$

$$
=\frac{10}{40} \times 100 \%
$$$$
=25 \%
$$

c. $\mathrm{P}=\frac{F}{N} \times 100 \%$

$$
=\frac{7}{40} \times 100 \%
$$$$
=17,5 \%
$$ 
Berdasarkan Tabel 4 di atas dapat diketahui bahwa terdapat 3 orang $(7,5 \%)$ yang berada pada kategori Sangat rendah, terdapat 20 orang $(50 \%)$ responden yang berada pada kategori Rendah, terdapat 10 orang $(25 \%)$ responden yang berada pada kategori Sedang dan terdapat 7 orang $(17,5 \%)$ responden yang berada pada kategori Tinggi. Berdasarkan hasil perhitungan tersebut diatas dapat disimpulkan bahwa secara umum kemampuan pemahaman konsep matematika siswa kelas $\mathrm{X}_{4}$ SMA Negeri 11 Makassar hal ini ditunjukkan dari perolehan nilai pada kategori rendah 50\% dari 40 siswa.

\section{B. Kemampuan Pemahaman Konsep Matematika Sesudah Penerapan Model Pemecahan Masalah DDFK di Kelas $\mathrm{X}_{4}$ SMA Negeri 11 Makassar.}

Hasil belajar siswa dideskripsikan berdasarkan analisis data tes awal (pre-test) dan data akhir (post-test). Data kemampuan pemahaman konsep matematika siswa kelas $\mathrm{X}_{4}$ SMA Negeri 11 Makassar setelah penerapan model pemecahan masalah $D D F K$ sebagai berikut mempunyai rata-rata (mean)

$$
\begin{aligned}
\bar{x} & =\frac{\sum_{i=1}^{k} x_{i}}{n} \\
& =\frac{3331}{40} \\
& =78,50
\end{aligned}
$$

Dari hasil perhitungan diatas diperoleh rata-rata nilai kemampuan pemahaman konsep matematika siswa kelas $\mathrm{X}_{4}$ SMA Negeri 11 Makassar setelah penerapan Model Pemecahan Masalah $D D F K$ yaitu 78,50 dari ideal 100 .
Tabel 3

Tingkat Penguasaan Materi (Posttest) Siswa Kelas $\mathrm{X}_{4}$ SMA Negeri 11 Makassar

\begin{tabular}{|c|c|c|c|c|}
\hline $\begin{array}{c}\mathrm{N} \\
\mathrm{o}\end{array}$ & Interval & Frekuensi & $\begin{array}{c}\text { Perse } \\
\text { ntase }\end{array}$ & $\begin{array}{c}\text { Kategori } \\
\text { Hasil Belajar }\end{array}$ \\
\hline 1 & $0-34$ & 0 & 0 & Sangat \\
2 & $35-54$ & 0 & 0 & Rendah \\
3 & $55-64$ & 4 & 10 & Rendah \\
4 & $65-84$ & 28 & 70 & Sedang \\
5 & $85-100$ & 8 & 20 & Tinggi \\
& & & & Sangat tinggi \\
\hline \multicolumn{2}{|c|}{ Jumlah } & 40 & 100 & \\
\hline
\end{tabular}

h. $\mathrm{P}=\frac{F}{N} \times 100 \%$

$$
=\frac{4}{40} \times 100 \%
$$$$
=10 \%
$$

i. $\mathrm{P}=\frac{F}{N} \times 100 \%$

$=\frac{28}{40} \times 100 \%$

$=70 \%$

j. $\quad \mathrm{P}=\frac{F}{N} \times 100 \%$

$=\frac{8}{40} \times 100 \%$

$=20 \%$

Berdasarkan Tabel 6 di atas dapat diketahui bahwa terdapat 4 orang (10\%) yang berada pada kategori Sedang, terdapat 28 orang $(70 \%)$ responden yang berada pada kategori Tinggi dan terdapat 8 orang (20\%) responden yang berada pada kategori Sangat tinggi. Berdasarkan hasil perhitungan tersebut diatas dapat disimpulkan bahwa secara umum kemampuan pemahaman konsep matematika siswa kelas $\mathrm{X}_{4}$ SMA Negeri 11 Makassar setelah penerapan Model Pemecahan Masalah DDFK dikategotikan tinggi dan sangat tinggi, hal ini ditunjukkan dari perolehan nilai pada 
kategori tinggi $70 \%$ dan sangat tinggi $20 \%$ dari 40 siswa.

\section{Efektivitas Penerapan Model Pemecahan Masalah DDFK terhadap Peningkatan Kemampuan Pemahaman Konsep Matematika pada Siswa Kelas $X_{4}$ SMA Negeri 11 Makassar.}

Sesuai dengan hipotesis penelitian yakni "Penerapan model pemecahan masalah DDFK efektif dalam meningkatkan kemampuan pemahaman konsep matematika siswa kelas $\mathrm{X}_{4}$ SMA Negeri 11 Makassar", maka teknik yang digunakan untuk menguji hipotesis tersebut adalah statistik F.

1) Menentukan Standar Deviasi

Tabel 4

Standar Deviasi Nilai Pretest

\begin{tabular}{|c|c|c|c|c|c|}
\hline Interval & $f_{i}$ & $x_{i}$ & $x_{i}-\bar{x}$ & $\left(x_{i}-\bar{x}\right)^{2}$ & $f_{i} \cdot\left(x_{i}-\bar{x}\right)^{2}$ \\
\hline $30-36$ & 6 & 33 & $-17,88$ & 319,69 & 1918,14 \\
\hline $37-43$ & 8 & 40 & $-10,88$ & 118,37 & 449,92 \\
\hline $44-50$ & 9 & 47 & $-3,88$ & 15,05 & 135,45 \\
\hline $51-57$ & 4 & 54 & 3,12 & 9,73 & 38,92 \\
\hline $58-64$ & 6 & 61 & 10,12 & 102,41 & 614,46 \\
\hline $65-71$ & 7 & 68 & 17,45 & 304,50 & 2131,50 \\
\hline Jumlah & & & & & 5288,39 \\
\hline
\end{tabular}

$$
s_{1}^{2}=\frac{\sum_{i=1}^{n} f_{i}\left(x_{i}-\bar{x}\right)^{2}}{n-1}
$$

$$
\begin{aligned}
& s_{1}^{2}=\frac{5288,39}{40-1} \\
& s_{1}^{2}=\frac{5288,39}{39} \\
& s_{1}^{2}= \\
& 135,60
\end{aligned}
$$

\section{Tabel 5}

Standar Deviasi Nilai Posttest

\begin{tabular}{|c|c|c|c|c|c|}
\hline Interval & $f_{i}$ & $x_{i}$ & $x_{i}-\bar{x}$ & $\left(x_{i}-\bar{x}\right)^{2}$ & $\begin{array}{c}f_{i} \cdot\left(x_{i}-\right. \\
\bar{x})^{2}\end{array}$ \\
\hline $60-66$ & 4 & 63 & $-15,50$ & 240,25 & 961 \\
\hline $67-73$ & 5 & 70 & $-8,50$ & 72,25 & 361,25 \\
\hline $74-80$ & 16 & 77 & $-1,50$ & 2,25 & 36 \\
\hline $81-87$ & 10 & 84 & 5,50 & 30,25 & 302,50 \\
\hline $88-94$ & 4 & 91 & 12,5 & 156,25 & 625 \\
\hline $95-101$ & 1 & 98 & 19,50 & 380,25 & 380,25 \\
\hline Jumlah & & & & & 2666 \\
\hline
\end{tabular}

$$
s_{2}^{2}=\frac{\sum_{i=1}^{n} f_{i}\left(x_{i}-\bar{x}\right)^{2}}{n-1}
$$$$
s_{2}^{2}=\frac{2666}{40-1}
$$$$
s_{2}^{2}=\frac{2666}{39}
$$

$$
s_{2}^{2}=68,36
$$


2) Menentukan harga $F_{\text {hitung }}$

$$
\begin{aligned}
F & =\frac{s_{1}^{2}}{s_{2}^{2}} \\
& =\frac{135,60}{68,36} \\
& =1,98
\end{aligned}
$$

3) Menentukan aturan pengambilan keputusan atau kriteria yang signifikan

Adapun kriteria keefektifannya adalah sebagai berikut :

a. Apabila $\mathrm{s}_{1}^{2}>\mathrm{s}_{2}^{2}$ atau $\mathrm{F}>0$, berarti model pemecahan masalah DDFK ini efektif dalam meningkatkan kemampuan pemahaman konsep matematika siswa kelas X SMA Negeri 11 Makassar.

b. Apabila $\mathrm{s}_{1}^{2} \leq \mathrm{s}_{2}^{2}$ atau $\mathrm{F} \leq 0$, berarti model pemecahan masalah DDFK ini tidak efektif dalam meningkatkan kemampuan pemahaman konsep matematika siswa kelas X SMA Negeri 11 Makassar.

4) Kesimpulan

Berdasarkan hasil analisis inferensial diatas di peroleh $s_{1}^{2}>s_{2}^{2}$ dimana, $s_{1}^{2}=135,60 \quad$ sedangkan $s_{2}^{2}=68,36 \quad$ dan $\quad F>0, \quad$ maka berdasarkan kriteria keefektifan dapat dikatakan bahwa model pemecahan masalah DDFK efektif dalam meningkatkan kemampuan pemahaman konsep matematika pada siswa kelas $\mathrm{X}$ SMA Negeri 11 Makassar.
Dengan demikian dapat disimpulkan bahwa model pemecahan masalah DDFK efektif dalam meningkatkan kemampuan pemahaman konsep matematika pada siswa kelas $\mathrm{X}$ SMA Negeri 11 Makassar.

\section{Hasil Observasi}

Tabel 6. hasil analisis aktivitas dan keterlaksanaan pembelajaran

\begin{tabular}{|l|c|c|}
\hline \multicolumn{1}{|c|}{ Aspek } & $\begin{array}{c}\text { Rata- } \\
\text { Rata }\end{array}$ & Kategori \\
\hline Aktivitas Siswa & 3,70 & Sangat Baik \\
\hline $\begin{array}{l}\text { Keterlaksanaan } \\
\text { Pembelajaran }\end{array}$ & 3,80 & $\begin{array}{c}\text { Terlaksana } \\
\text { dengan baik }\end{array}$ \\
\hline
\end{tabular}

\section{E. PEMBAHASAN}

Penelitian ini merupakan penelitian eksperimen dengan jenis penelitian pre eksperimen desaign dengan desain penelitian yang digunakan yaitu One Group Pretest Posttest Design yaitu eksperimen yang dilaksanakan pada satu kelompok saja tanpa kelompok pembanding. Pada desain ini menggunakan pretest sebelum diberi perlakuan dan post test setelah diberi perlakuan. Dengan demikian hasil perlakuan dapat diketahui lebih akurat.

Dalam penelitian ini dilakukan dua tahap yaitu tahap persiapan dan tahap pelaksanaan.

Pertama, Tahap persiapan. Pada tahap persiapan ini dilakukan beberapa hal, yaitu menelaah kurikulum materi pelajaran 
matematika untuk kelas $\mathrm{X}_{4}$ SMA Negeri 11 Makassar, menyusun langkah-langkah model pemecahan masalah DDFK yang akan diterapkan pada siswa, melakukan konsultasi dengan pihak sekolah mengenai rencana teknis penelitian, membuat skenario pembelajaran di kelas dalam hal ini pembuatan silabus dan Rencana Pelaksanaan Pembelajaran (RPP) sesuai materi yang akan diajarkan, membuat alat bantu atau media pengajaran bila diperlukan, membuat lembar observasi untuk mengamati bagaimana kondisi belajar mengajar ketika pelaksanaan berlangsung, dan membuat soal-soal untuk tes awal (pretest).

Kedua, Tahap pelaksanaan. Dalam tahap pelaksanaan ini dilakukan dua fase yaitu pre-perlakuan dan perlakuan. Preperlakuan yang dilaksanakan meliputi; meberikan penjelasan secara singkat dan menyeluruh terhadap siswa kelas $\mathrm{X}_{4}$ SMA Negeri 11 Makassar sehubungan dengan materi yang akan diteliti. Penjelasan singkat ini diberikan pada saat sebelum dilakukan tes awal (pretest). Penjelasan singkat ini hanya mencakup hal-hal yang bersifat umum saja terkait materi yang akan diteliti. Setelah itu diberikanlah tes awal (pretest) dengan menggunakan instrumen tes untuk mengetahui hasil belajar siswa sebelum model pemecahan masalah DDFK diterapkan. Pada pelaksanaan pretest diikuti oleh siswa kelas $\mathrm{X}_{4}$ SMA Negeri 11 Makassar yang berjumlah 40 orang. Nilai rata-rata (Mean) yang diperoleh yaitu 50,88, jika dimasukkan dalam kategori hasil belajar siswa maka persentase hasil belajar siswa adalah 50\% dikategorikan rendah. Langkah selanjutnya yaitu perlakuan, dalam hal ini memberikan perlakuan dengan menggunakan model pemecahan masalah DDFK. Dalam penerapan model pemecahan masalah DDFK ini, materi yang dipelajari adalah Trigonometri yaitu tentang rumusrumus segitiga dan model matematika yang berhubungan dengan trigonometri. Namun untuk mempelajari hal tesebut, siswa dituntut untuk memahami terlebih dahulu mengenai Dalil Phytagoras dan semua sifatsifat segitiga. Guru melakukan apersepsi dengan mengajukan pertanyaan-pertanyaan yang berguna untuk mengingatkan kembali materi prasyarat. Dalam hal ini yaitu mengenai Dalil Phytagoras dan semua sifatsifat segitiga. Selanjutnya siswa diberikan masalah berupa latihan soal dan diminta mengerjakannya secara individu. Agar lebih sistematis, dalam penyelesaiannya siswa diarahkan untuk menggunakan model pemecahan masalah DDFK (Definisi, Desain, Formulasi, dan Komunikasi). Dalam hal ini siswa diarahkan untuk dapat mendefinisikan masalah, mendesain solusi, memformulasikan hasil, dan mengomunikasikan hasil. Sementara siswa mengerjakan soal, guru berkeliling mengontrol dan membimbing siswa yang mengalami kesulitan. Akhirnya dengan bantuan dan bimbingan dari guru, para siswa pun dapat memahami dan menyelesaikan masalah pada soal latihan yang diberikan. Setelah para siswa menyelesaikan soal latihan, guru mempersilahkan perwakilan salah satu dari siswa untuk 
mempersentasikan hasil pekerjaannya. Karena terdapat siswa yang memiliki jawaban yang berbeda, maka siswa tersebut mempersentasikan hasil pekerjaannya. Kemudian guru bertindak sebagai fasilitator untuk meluruskan dan menyimpulkan materi yang dipelajari. Guru juga memberi kesempatan siswa untuk bertanya jika masih ada materi yang belum dipahami. Di akhir pembelajaran, guru meminta siswa untuk mengumpulakan hasil pekerjaannya untuk memberikan penghargaan dalam pekerjaannya berupa penilaian berdasarkan hasil pekerjaannya. Perlakuan ini dengan menerapkan model pemecahan masalah DDFK dilaksanakan sebanyak 3 kali pertemuan.

Untuk mengetahui apakah ada peningkatan hasil belajar siswa setelah diberikan perlakuan dengan menerapkan model pemecahan masalah DDFK maka diadakan posttest. Nilai rata-rata yang diperoleh pada posttest yaitu 78,50, apabila dimasukkan dalam kategori hasil belajar siswa maka hasil posttest dikategorikan tinggi dengan persentase hasil belajar $70 \%$ dan kategori sangat tinggi dengan persentase hasil belajar 20\% Maka dalam pelaksanaannya dapat dilihat bahwa ada peningkatan hasil belajar dari sebelum ke sesudah diterapkan model pemecahan masalah DDFK. Peningkatan tersebut terlihat jelas dari rata-rata nilai pretest 50,88 meningkat pada rata-rata nilai posttest 78,50 . Untuk mengetahui tingkat keberhasilan kemampuan pemahaman kosep siswa juga digunakan lembar obsevasi.
1. Lembar observasi terhadap guru

Berdasarkan data hasil observasi terhadap guru dengan menggunakan langkah-langkah model pemecahan masalah DDFK dapat diketahui persentase ketuntasan perlakuan model pemecahan masalah DDFK sebagai berikut:

a. Aktifitas siswa sangat baik dengan ratarata 3.70 dari ideal 4,00

b. Keteraksanaan pembelajaran terlaksana denganbaik dengan rata-arata 3,80 dari ideal 4,00

Dari uraian di atas maka dapat disimpulkan bahwa penerapan model pemecahan masalah DDFK dapat meningkatkan kemampuan pemahaman konsep matematika siswa kelas $\mathrm{X}_{4}$ SMA Negeri 11 Makassar.

Efektivitas penerapan model pemecahan masalah DDFK dapat diketahui dengan menganalisis hasil pretest dan posttest dengan menggunakan uji $\mathrm{F}$ dimana didapatkan $s_{1}^{2}>s_{2}^{2}$ yaitu $s_{1}^{2}=135,60$ lebih besar dari $s_{2}^{2}=68,36$. Dengan ketentuan Apabila $\mathrm{s}_{1}^{2}>\mathrm{s}_{2}^{2}$ atau $\mathrm{F}>0$, berarti model pemecahan masalah DDFK ini efektif dalam meningkatkan kemampuan pemahaman konsep matematika siswa kelas $\mathrm{X}_{4}$ SMA Negeri 11 Makassar. Dengan demikian penerapan model pemecahan masalah $D D F K$ efektif digunakan.

\section{KESIMPULAN}

Adapun kesimpulan yang dapat diambil dari hasil penelitian ini adalah sebagai berikut: 
1. Berdasarkan data yang diperoleh dapat disimpulkan bahwa secara umum kemampuan pemahaman konsep matematika siswa kelas $\mathrm{X}_{4}$ SMA Negeri 11 Makassar sebelum penerapan model pemecahan masalah DDFK dikategorikan rendah. Hal ini ditunjukkan dari perolehan persentase pada kategori rendah sebesar $50 \%$ dengan nilai rata-rata 50,88 dari 40 siswa.

2. Berdasarkan data yang diperoleh dapat disimpulkan bahwa secara umum kemampuan pemahaman konsep matematika siswa kelas $\mathrm{X}_{4}$ SMA Negeri 11 Makassar setelah penerapan model pemecahan masalah DDFK dikategorikan tinggi dan sangat tinggi. Hal ini ditunjukkan dari perolehan persentase pada kategori tinggi sebesar $70 \%$ dan pada kategori sangat tinggi sebesar $20 \%$ dengan nilai rata-rata 78,50 dari 40 siswa.

3. Berdasarkan data dari hasil analisis inferensial untuk instrumen dalam bentuk tes menunjukkan nilai $s_{1}^{2}=$ 135,60 dan nilai $s_{2}^{2}=68,36$ sehingga nilai $\mathrm{F}$ yang dicari $=1,98$. Dengan demikian $\mathrm{s}_{1}^{2}>\mathrm{s}_{2}^{2}$ atau $\mathrm{F}>0$, berarti model pemecahan masalah DDFK efektif dalam meningkatkan kemampuan pemahaman konsep matematika siswa kelas $\mathrm{X}_{4}$ SMA Negeri 11 Makassar.

\section{DAFTAR PUSTAKA}

Dahar, R.W. Teori-teori Belajar.Jakarta: Erlangga, 1988.

Depdikbud. Pedoman umum sistem pengujian hasil kegiatan belajar. www.google.com, 2010.

Gulo, W. Strategi Belajar-Mengajar. Jakarta: PT Gramedia, 2008.

Hasan, M.Iqbal. Pokok-Pokok Materi Statistic 2. Jakarta: Bumi Aksara, 1999.

Khairunnisa, Vera. Perbandingan Peningkatan Kemampuan Pemahaman Konsep Matematis Antara Siswa yang Memperoleh Pembelajaran Melalui Model Pemecahan Masalah "DDFK"dengan yang memperoleh Pembelajaran Konvensional. [Online]. Tersedia: http://repository.upi.edu/operator/upl oad/spgsdo806317chapter1.pdf, 2010.

Kusmawan, U. Model Instruksional DDFK Problem Solving. [Journal Online]. Tersedia: http://pk.ut.ac.id/jp/21udan.htm, 2001

Ruseffendi, E.T. Pengantar kepada Membantu Guru Mengembangkan Kompetensinya dalam Pengajaran Matematika untuk Meningkatkan CBSA. Bandung: Tarsito, 2005. 
Shadiq, Fadjar . Psikologi Pembelajaran

Matematika di SMA. Pusat

Pengembangan dan Pemberdayaan

Pendidikan dan Tenaga

Kependidikan Matematika:

Yogyakarta, 2008.

Sugiyono. Metode Penelitan Pendidikan Pendekatan Kuantitatif, Kualitatif, dan $R \& D$. Bandung: Alfabeta, 2008.

Suherman, Erman. Strategi Pembelajaran Matematika Kontemporer. Universitas Pendidikan Indonesia, 2003.

Tiro, Muh. Arif.. Dasar-dasar statistik. Makassar: State University Of Makassar Press, 2000.
Yusefendi. Meningkatkan Kemampuan dan Penalaran Matematika siswa SMA dengan Menggunakan Pembelajaran Berbasis Masalah (Problem Based Learning). [Journal Online]. Tersedia: http://www.yusefendi.co.ccl, 2010.

\section{Profil Penulis}

Penulis adalah Dosen Program Studi Pendidikan Matematika, STKIP Muhammadiyah Enrekang. 